\title{
WEED SCIENCE
}

\section{PHYSIOLOGY, CHEMISTRY, AND BIOCHEMISTRY}

Giant Foxtail (Setaria faberi) Resistance to Aryloxyphenoxypropionate and Cyclohexanedione Herbicides. David E. Stoltenberg and Ronald J. Wiederholt

Absorption, Translocation, and Metabolism of AC 263,222 in Selected Soybean (Glycine max) Cultivars. Larry J. Newsom, David R. Shaw, and Thomas F. Hubbard, Jr.

The Basis for the Hard-Water Antagonism of Glyphosate Activity. Kurt D. Thelen, Evelyn P. Jackson, and Donald Penner

Uptake, Translocation, and Metabolism of ${ }^{14} \mathrm{C}$-MSMA in Organic Arsenical-Resistant and -Susceptible Mississippi Biotypes of Common Cocklebur (Xanthium strumarium L.). Chandrashekhar I. Nimbal, Gene D. Wills, Stephen O. Duke, and David R. Shaw

Soil Temperature and Water Effects on Dissipation of Commercial and Starch Encapsulated Atrazine Formulations. Gordon D. Vail, Michael V. Hickman, and Marvin M. Schreiber

Response of a Chlorsulfuron-Resistant Biotype of Kochia scoparia to ALS Inhibiting Herbicides and Piperonyl Butoxide. Chae Soon Kwon and Donald Penner

Utility of Nuclear Magnetic Resonance for Determining the Molecular Influence of Citric Acid and an Organosilicone Adjuvant on Glyphosate Activity. Kurt D. Thelen, Evelyn P. Jackson, and Donald Penner

Absorption, Translocation, and Metabolism of Imazethapyr in Common Ragweed (Ambrosia artemisiifolia) and Giant Ragweed (Ambrosia trifida). Thomas O. Ballard, Michael E. Foley, and Thomas T. Bauman

Magnitude of Imazethapyr Resistance of Corn (Zea mays) Hybrids with Altered Acetolactate Synthase. Randall S. Currie, Chae S.

Kwon, and Donald Penner

\section{WEED BIOLOGY AND ECOLOGY}

Seed Viability and Dormancy of 17 Weed Species after 9.7 Years of Burial in Alaska. Jeffrey S. Conn and Richard E. Deck

Using Plant Volume to Quantify Interference in Corn (Zea mays) Neighborhoods. Brett H. Bussler, Bruce D. Maxwell, and Kiaus J. Puettmann

PALWEED:WHEAT: A Bioeconomic Decision Model for Postemergence Weed Management in Winter Wheat (Triticum aestivum). Tae-Jin Kwon, Douglas L. Young, Frank L. Young, and Chris M. Boerboom

The Stability of Weed Seedling Population Models and Parameters in Eastern Nebraska Corn (Zea mays) and Soybean (Glyơine max) Fields. Gregg A. Johnson, David A. Mortensen, Linda J. Young, and Alex R. Martin . . . . . . . . . . . . . . . . . . . .

Empirical Models of Pigweed (Amaranthus spp.) Interference in Soybean (Glycine max). Anita Dieleman, Allan S. Hamill, Stephan

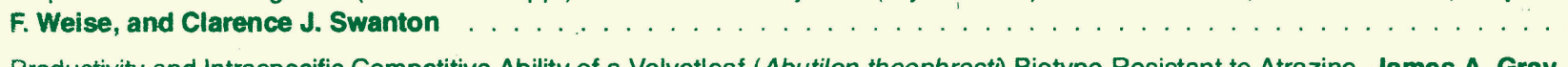
Productivity and Intraspecific Competitive Ability of a Velvetleaf (Abutilon theophrasti) Biotype Resistant to Atrazine. James A. Gray, David E. Stoltenberg, and Nelson E. Balke

Effects of Photoperiod on Reproductive Development in Velvetleaf (Abutilon theophrasti). David T. Patterson

\section{WEED MANAGEMENT}

The Concept and Application of Early Economic Period Threshold: The Case of DCPA in Onions (Allium cepa). Claudio M. Dunan, Philip Westra, Edward E. Schweizer, Donald W. Lybecker, and Frank D. Moore III 
Growth and Yield of Pea (Pisum sativum L.) and Lentil (Lens culinaris L.) Sprayed with Low Rates of Sulfonylurea and Phenoxy Herbicides. David R. Gealy, Chris M. Boerboom, and Alex G. Ogg, Jr. . . . . . . . . . . . . . . . . . . . . . . . .

Effects of Rotational Crop Herbicides on Rice (Oryza sativa). David H. Johnson, J. Dwayne Beaty, Diana K. Horton, Ronald E. Talbert, Charles B. Guy, John D. Mattice, Terry L. Lavy, and Roy J. Smith, Jr.

Influence of Soil-Applied Herbicides on Ivyleaf Morningglory (Ipomoea hederacea) Growth and Development in Soybean (Glycine max). James C. Holloway, Jr. and David R. Shaw .

Sugarcane (Saccharum spp.) Response to Simulated Fluazifop-P Drift. Edward P. Richard, Jr. . . . . . . . . . . . . . . . . . . 660

Effect of Rainfall on Glyphosate Plus 2,4-D Performance on Echinochloa crus-galli. Gail A. Wicks and Gordon E. Hanson . . . . . 666

\section{SOIL, AIR, AND WATER}

Effects of Ground Cover and Formulation on Herbicides in Runoff Water from Miniature Nursery Sites. P. Chris Wilson, Ted Whitwell, and Melissa B. Riley

Sorption, Mobility and Degradation of Triclopyr and 2,4-D on Four Soils. William G. Johnson, Terry L. Lavy, and Edward E. Gbur

\section{SPECIAL TOPICS}

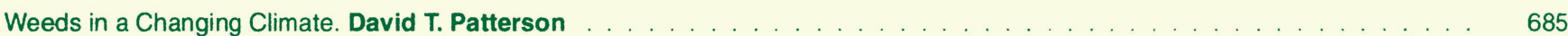

Minutes of the WSSA Board of Directors Meeting, January 29 and 30,1995 , Seattle, Washington . . . . . . . . . . . . . . 702

Minutes of the WSSA Business Meeting, January 31,1995 , Seattle, Washington . . . . . . . . . . . . . . . . . 707

Minutes of the WSSA Board of Directors Meeting, Thursday, February 2,1995 , Seattle, Washington . . . . . . . . . . . . 710

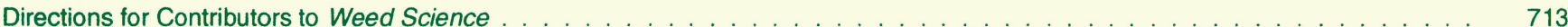

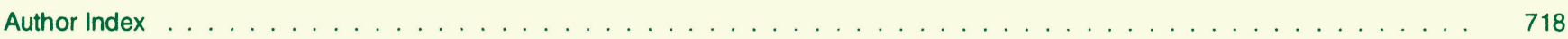

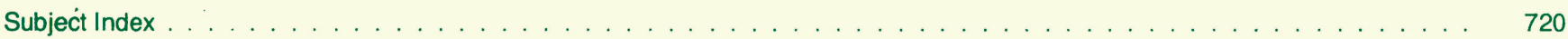




\section{WEED SCIENCE}

Published four times a year by the Weed Science Society of America

Robert L. Zimdahl, Editor

\section{Associate Editors}

D. D. Buhler, USDA-ARS, National Soil Tilth Lab, 2150 Pammel Dr., Ames, IA 50011

Nicholas Jordan, Dept. Agron/Plant Genetics, Univ. of Minnesota, 1991 Buford Circle, St. Paul, MN 55108

R. J. Kremer, USDA-ARS, 144 Mumford Hall, University of Missouri, Columbia, MO 65211

Tom Mueller, Plant/Soil Science Department, University of Tennessee, P.O. Box 1071, Knoxville, TN 37901

Karen Ann Renner, Crop and Soil Sciences, Michigan State University, 466 Plant/Soil Science Bldg., E. Lansing, MI 48824

Dale Shaner, American Cyanamid Co., P.O. Box 400, Princeton, NJ 08540

C. E. Snipes, Delta Branch Exp. Sta., P.O. Box 197, Stoneville, MS 38776

Susan E. Weaver, Agriculture Canada, Research Station, Harrow, ON, Canada N0R 1G0

Allen F. Wiese, Texas Agricultural Experiment Station, Texas A\&M University System, P.O. Box Drawer 10, Bushland, TX 79012

Lori J. Wiles, Great Plains Systems Res., USDA ARS, 301 S. Howes, Rm. 353, Ft. Collins, CO 80522

Gayle Rodcay, Technical Editor

Reviewers

$\begin{array}{ll}\text { R. E. Blackshaw } & \text { Stephen Hart } \\ \text { Jim Burton } & \text { Robert Hartzler } \\ \text { A. G. Dexter } & \text { W. Carroll Johnson } \\ \text { William E. Dyer } & \text { Wayne Keeling } \\ \text { Michael E. Foley } & \text { Martin A. Locke }\end{array}$

R. E. Blackshaw

Jim Burton

A. G. Dexter

Michael E. Foley

Carol Mallory-Smith
Diane R. Manthey
Bruce Maxwell
Wondi Mersie
Krishna Reddy
Jill Schroeder

Carol Mallory-Smith

David Shaw

Redi Smeda

Tracy Sterling

C. J. Swanton

Ronald F. Turco

\author{
Thomas Tworkoski \\ M. K. Upadhyaya \\ Glenn Wehtje \\ Leslie A. Weston \\ John Wilcut
}

\section{Officers of the Weed Science Society of America}

James L. Barrentine, President

Stephen O. Duke, President-Elect

Calvin G. Messersmith, Vice President

Alex G. Ogg, Past President
Charlotte Eberlein, Secretary

Laura L. Whatley, Treasurer

Ann Legere, Editor-in-Chief

Robert A. Schmidt, Executive Secretary

Horace D. Skipper, Chair, Constitution and Operating Procedures

Weed Science (ISSN 0043-1745) is an official publication of the Weed Science Society of America, 1508 West University Ave., Champaign, IL 61821-3133 (AC/217-352-4212). It contains refereed papers describing the results of research that elucidates the nature of phenomena relating to all aspects of weeds and their control. It is published quarterly, one volume per year, four issues per year beginning in January.

Membership is \$60 per year, student affiliate membership \$20, which includes receipt of Weed Science, Weed Technology, and WSSA Newsletter. Dues should be sent to WSSA, 1508 West University Ave., Champaign, IL 61821-3133 not later than December 1 of each year. Membership in the society is on a calendar-year basis only.

Subscriptions (institutions, libraries, etc.) are $\$ 100$ per year, one volume per year of four issues beginning in January. New subscriptions and renewals begin with the first issue of the current volume and should be sent to WSSA, 1508 West University Ave., Champaign, IL 61821-3133.

Change of address affecting the mailing list for members, students, and subscribers, inquiries about copies lost in the mail, requests for back issues, and all matters pertaining to the receipt of the Journal, membership and subscription information should be sent to WSSA, 1508 West University Ave., Champaign, IL 61821-3133. Claims for copies lost in the mail must be received within 30 days ( 90 days foreign) of the date of issue to insure replacement at no charge.

Manuscripts must be sent to the Editor, Robert L. Zimdahl, Weed Research Laboratory, Colorado State University, Fort Collins, CO 80523 . Directions for contributors are published in the October-December issue of Weed Science. Authors are asked to pay $\$ 50$ (member) or $\$ 100$ (nonmember) per page charge as a portion of the cost of publication. The Editor can make exceptions in advance when justified.

The Weed Science Society of America fully subscribes to the belief that progress in science depends upon the sharing of ideas, information, and materials among qualified investigators. Authors of papers published in Weed Science are therefore encouraged, whenever practicable and when state and federal laws permit, to share genotypically unique, propagative materials they might possess with other workers in the area who request such materials for the purpose of scientific research.

Weed Science published by the Weed Science Society of America.

Second class postage paid at Champaign, IL and at additional mailing offices.

Copyright 1995 by the Weed Science Society of America. Printed in USA.

All rights reserved. Reproduction in part or whole prohibited.

PuSTMASnR: Send address changes to WSSA, 1508 West University Ave.. Champaign, IL 61821-3133. 


\section{Sustaining Members \\ WEED SCIENCE SOCIETY OF AMERICA \\ September 15, 1995}

\author{
Patron \\ BASF Corporation \\ Cenex/Land O'Lakes \\ Compliance Service Int'l., Inc. \\ DowElanco \\ DuPont Agricultural Products \\ ISK Bioscience Corporation \\ Monsanto Agricultural Company \\ Sandoz Crop Protection \\ Valent USA Corporation

\section{Contributing} \\ AgrEvo USA Company \\ FMC Corporation Ag Chem Group \\ Griffin Corporation \\ Miles Inc. \\ O M Scott \& Sons Company \\ PBI/Gordon Corporation \\ Terra Chemical Int'l. Inc. \\ Uniroyal Chemical Company
}

\section{Associate}

Agri-Growth Research Inc.

Agvise Laboratories

A \& L Agric. Laboratories Inc.

ALMACO Company

American Agricultural Services

American Cyanamid Company

Analytical Bio-Chemistry Lab.
Ciba-Geigy Canada Ltd.

Ciba-Geigy Corporation

Concord Environmental Equipment

Decagon Devices, Inc.

Deere \& Company Tech. Center

Ecologistics Limited

EPL Bio-Analytical Services

Gandy Corporation

Growmark Inc.

Gylling Data Management Inc.

HarvestMaster Inc.

Heartland Technologies Inc.

\section{ICMS}

Kincaid Equipment Manufacture Corp.

Landis International Inc.

LI-COR Inc.

MARATHON Ag/Environmental

Minnesota Valley Testing Lab.

Mycogen Corporation

Nissan Chemical America Group

R \& D Sprayers, Inc.

Research Options Inc.

Rhone-Poulenc Ag Company

Rohm \& Haas Company

Spraying Systmes Company

Springborn Laboratories Inc.

Stewart Agric. Research Services

The Andersons

Thomson Publications

United Agri Products

Weed Systems Equipment Inc.

Wintersteiger America Inc.

ZENECA Inc. 